\title{
Synthesis and Investigation of 2-Propylpentanoyl Amino Acid and Dipeptide Conjugates as Novel Anticonvulsants
}

\author{
S.A. Abd El-Latef, F.A. Ragab*, W.I. El-Eraky ${ }^{* * *}$ and M.H. \\ Abo-Ghalia ${ }^{\#}$ \\ Peptide Chemistry Department, National Research Centre, \\ *Pharmaceutical Chemistry Department, Faculty of Pharmacy, \\ Cairo University, and **Pharmacology Department, National \\ Research Centre, Cairo, Egypt.
}

$\mathbf{T}$

HE CENTRAL nervous system (CNS) requires the anticipation of a number of neuro-active amino acids and peptides ${ }^{(1)}$ for its normal function. Thus, $\gamma$ aminobutyric acid $(G A B A)$, glycine, histadine, tyrosine, arginine, taurine, aspartic and glutamic acids, are involved in the synthesis of neurotransmitters neuromodulators, or their neuro-agonists. In particular, glycine is an inhibitory neurotransmitter ${ }^{(1)}$ that is found in mammalian proteins and tissues. Its role primarily appears to involve the inhibition of neuronal activity in the striatum, substantia nigra and cerebellum. Analougously, $\gamma$-aminobutyric acid (GABA) ${ }^{(2)}$ is a constituent of mammalian tissues particularly the brain and spinal cord. It is synthesized in GABA ergic neurons, and interacts with postsynaptic receptors to exert its inhibitory effects.

On the other hand, the collective terms "convulsive disorders", "seizure disorders" and "cerebral seizures" are currently, synonymously considered, for epileptic convulsions. Such disorders are common neurological symptoms of a complex nature and, frequently, undetermined etiologies.

With the existing medications, however, approximately $25 \%$ of epileptic patients are not seizure free, regardless of their therapy optimization. In addition to the apparent health hazards, considerable socio-economic problems are intrinsically encountered with the prevalence of untreated epilepsy.

In that context, 2-propylpentanoic acid (generic name: Valproic Acid (trade names: Depakene ${ }^{\circledR, ~ “ A b b o t t ~ L a b ”) ~ i s ~ o n e ~ o f ~ t h e ~ e s s e n t i a l ~ a n t i e p i l e p t i c s, ~ t h a t ~ a r e ~}$ still predominant in the current clinical practice ${ }^{(3)}$.

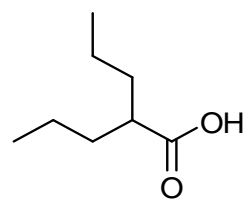

Valproic Acid, 2-propylpentanoic acid (VPA), CAS: 99-66-1

${ }^{\#}$ Corresponding : author, email: nrc.peptides.egypt@ gmail.com 
The use of valproic acid as an anticonvulsant, however, is frequently restricted by its two potentially life-threatening, side effects, namely, teratogenicity $^{(4)}$ and hepatotoxicity ${ }^{(5)}$.

It is noteworthy to mention that neither GABA nor Glycine, as nero-inhibitor amino acids, are antiepileptically effective upon oral or systemic administration since they can't cross blood brain barrier ${ }^{(8)}$. Furthermore, the dipeptides glycylglycine, glycylglycinamide and gabaloyl-glycinamide did not manifest a significant anticonvulsant activity following i.p. administration to mice. However, valproyl conjugates of amino acids, particularly their amides, appeared recently as attractive anticonvulsant candidates ${ }^{(6,7)}$.

While glycinamide alone is active only when it is combined with a lipophilic anchor such as benzyl, acetyl, or benzyloxycarbonyl (Z-group), to be promoted to into an anticonvulsant active entity ${ }^{(9)}$. Contrarily, $\mathrm{N}^{\alpha}$-valproyl glycine amide showed a promising anticonvulsant profile in the screening of animal antiepileptic models, due to its better pharmacokinetic profile ${ }^{(6,10)}$. Moreover, it was interestingly reported that it acts as a novel drug, while doesn't serve as a chemical delivery system or a prodrug for either of its components: valproic acid or glycine ${ }^{(11)}$.

\section{Results and Discussion}

Some rationalized novel amino acid and peptide conjugates of the antiepileptic drug "Valproic Acid" were, herein, chemically synthesized, characterized and pharmacologically investigated for their anticonvulsant potency.

The hereinafter general structural formula represents the molecular edifice of the newly synthesized anticonvulsant candidates:<smiles>[R]C(=O)C[R]C(=O)C(CCC)CCC</smiles>

$\mathrm{R}_{1}$ :- amino acid or dipeptide residue; $\mathrm{R}_{2}$ :-OR (estres), - $\mathrm{NH}-\mathrm{NH}_{2}$ (Hydrazides; $\mathrm{NH}-\mathrm{N}=\mathrm{CHR}_{3}$ (Schiffs' bases; $\mathrm{R}_{3}$, aldehyde residue), $-\mathrm{COOH}$ (acids), $-\mathrm{NH}_{2}$ (amides).

Generally, the followed synthetic procedures for preparing the candidates are those frequently manipulated in amino acid and synthetic peptide chemistry for mild amide and peptide bond formation, namely, acid chloride, carbodiimides and mixed anhydride procedures ${ }^{(12,13)}$.

Egypt. J. Chem. 53, No. 2 (2010) 
Synthesis of $N$-valproyl amino acid esters

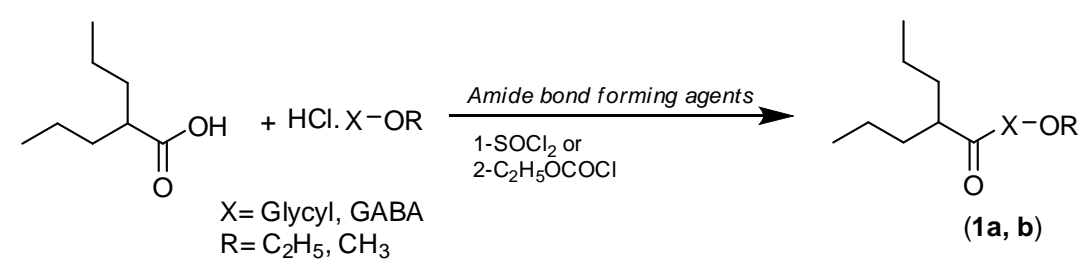

The ester function is known as versatile synthetic identity, easily to be hydrolyzed, or hydrazinolysed to its corresponding acids or hydrazides, respectively. However, both valproyl amino acid esters and valproyl amino acids as revealed by the literature investigation, are of limited interest as anticonvulsant agents ${ }^{(6)}$.

The following synthetic procedure is based upon coupling valproyl chloride, at low temperature, with free Gly-OEt or GABA-OMe, in the presence of $\mathrm{N}$ methyl morpholine, as a tertiary base.

Alternatively, the formation of valproyl mixed anhydride with ethylchloroformate at $\left(\sim-15^{\circ} \mathrm{C}\right.$, in the presence of a tertiary base) followed by in situ, coupling of formed mixed anhydride with free Gly-OEt or GABA-OMe, was equally, manipulated

The acid chloride method, however, proved to be more advantageous than the mixed anhydride method in several aspects as the stability of the stating acid chloride and overall reaction yield.

Synthesis of $N^{\alpha}$-Valproyl glycyl hydrazones

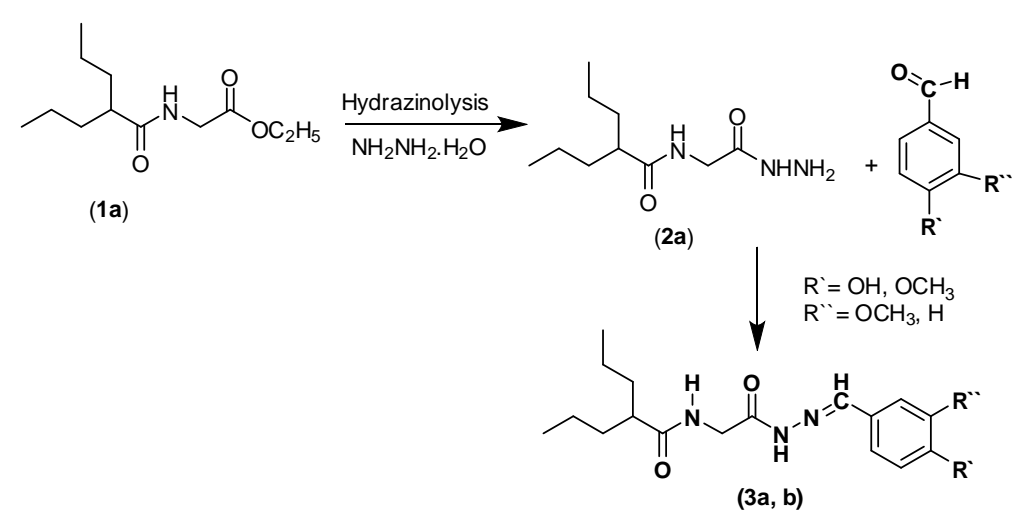

Egypt. J. Chem. 53, No. 2 (2010) 
The selection of $p$-anisaldehyde and 4-hydroxy-3-methoxy-benzaldehyde (Vaniline) as the carbonyl components for the two synthesized Schiffs' bases, is rationalized by the reported individual neurological activities of these aldehydes $^{(14)}$. In particular, for $p$-anisaldehyde, several studies were realized to investigate the anticonvulsant effects of the essential oils including aldehydes in Pimpinelle anisum fruit ${ }^{(15,16)}$.

Firstly $\mathrm{N}^{\alpha}$-valproyl glycine ethyl ester (1a) was converted to hydrazide via their reaction with hydrazine hydrate in methanol, affording the corresponding hydrazide (2a) in a $79 \%$ yield. Hydrazide (2a) was then condensed with vanillin or p-anisaldehyde. The hydrazones $3 \mathrm{a}$ and $3 \mathrm{~b}$ were, conveniently, obtained in 70 and $40 \%$ yields, respectively.

\section{Synthesis of $N$-valproyl dipeptide derivatives}

Assembling a conjugatable peptide backbone for biologically active candidates, is generally associated with an enhanced affinity for the encountered biological receptors. Consequently, an ameliorated biological activity is generally realized. Two peptide coupling methods were experimented for the synthesis of the novel valproyl dipeptides, namely, the mixed anhydride, and diisopropylcarbodiimide procedures.<smiles>[R]O[X]C(=O)C(CCC)CCC</smiles>

(1a, b)
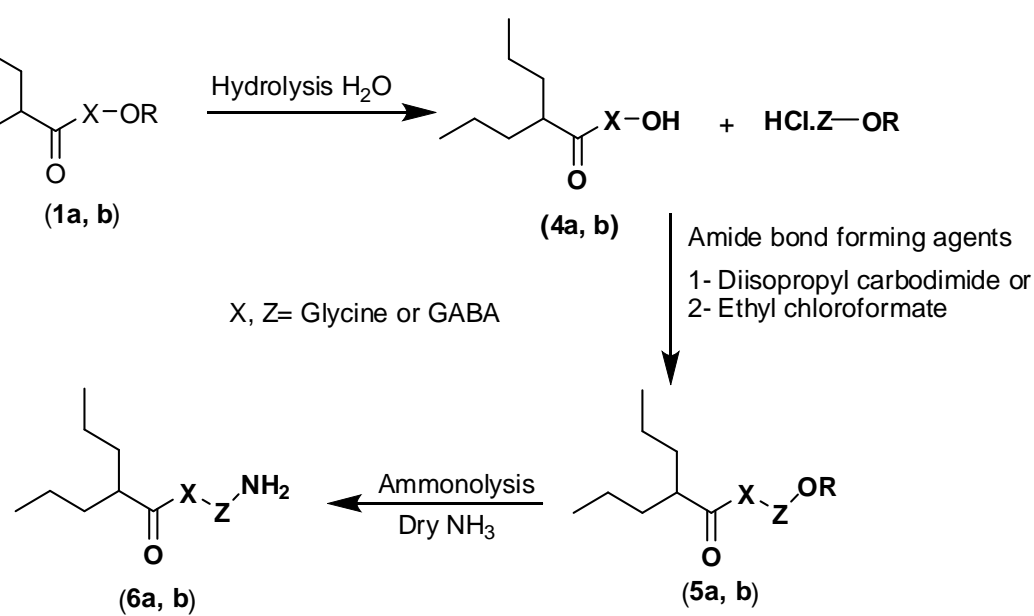

For the mixed anhydride method the synthesis was based upon its formation with ethylchloroformate and valproyl amino acids $(4 a, b)$ in the presence of $\mathrm{N}$ methyl morpholine (NMM) as a tertiary base. Coupling with GABA OMe or Gly $\mathrm{OEt}$, to afford ( $\mathrm{Va}-\mathrm{b})$ in $80-85 \%$ yield, respectively was then followed. 
An alternative method involved the coupling of $\mathrm{N}^{\gamma}$-valproyl GABA (4b) with glycine OEt in the presence of the water soluble diisopropylcarbodiimide (DIC) affording (5b), in a $48 \%$ yield.

The mixed anhydride method, as used for the synthesis of the valproyl dipeptide ester (5b), proved, however, to be more advantageous than the DIC method in several aspects, exemplified by the associated higher yields, as well as minimizing the side products, in contrast to the difficulty encountered in the complete removal of diisopropylurea, as the main side product of DIC method.

The suggestion of synthesis of valproyl dipeptide amides was rationalized by the literature reports that two valproyl amino acid amides, namely that of glycine and taurine have a pronounced anticonvulsant activity. In addition, mechanistically, the reported candidates were not acting as prodrugs for valproic acid, contrarily, as novel integrated agents ${ }^{(6,10)}$.

Ammonolosis of valproyl dipeptide esters $(5 \mathrm{a}, \mathrm{b})$ with methanolic dry ammonia afforded the corresponding valproyl diepeptide amides (6a, b) in 89 and $85 \%$ yields.

\section{Experimental}

Purity of the synthesized compounds was evidenced by TLC and their elemental analysis which was, generally, found to be within \pm 0.4 of the calculated theoretical values.

Melting points were determined in opened glass capillary tubes with an Electro thermal" digital melting point apparatus, (Model: IA9100- England) and were uncorrected. Infrared spectra $(\mathrm{KBr})$ were recorded on "Nexus 670 FTIR Nicolet" Fourier Transform Infrared Spectrometer, USA, within the range 4000$400 \mathrm{~cm}^{-1}$. Proton nuclear magnetic resonance $\left({ }^{1} \mathrm{H}-\mathrm{NMR}\right)$ spectra $\left(\mathrm{CDCl}_{3}\right.$ or DMSO) were run in a Jöel ((Japan, 270 or $500 \mathrm{MHz})$ spectrometer where TMS is considered as an internal standard. Mass spectra were run on "MAT Finnigan SSQ 7000 spectrometer" (Germany), using the electron impact (EI) technique. Elemental (micro-analysis) for the prepared compounds (Carbon, Hydrogen and Nitrogen, Microanalytical Unit, NRC, Cairo). Analytical thin layer chromatography (TLC) was performed on "Silica Gel" aluminium sheets, $60 \mathrm{~F}_{254}$ (E. Merck).

Synthesis of $N$-valproyl amino acid esters

Acid chloride method

A cold solution of valproic acid $\left(\sim 20 \mathrm{mmol}, \sim-5^{\circ} \mathrm{C}\right)$ and thionyl chloride $(3 \mathrm{ml}$; $\sim 20$ mmole), to which was added dimethylformamide $(0.5 \mathrm{ml})$, was stirred for an hour. The reaction mixture was then refluxed for an additional hour, evaporated to dryness and triturated with benzene to afford the corresponding acid chloride in a $90 \%$ yield. 
A THF solution of valproyl chloride (1 mmole) was dropwisely added to a cold $\left(-15^{\circ} \mathrm{C}\right)$ and stirred solution of the amino acid ester $(1 \mathrm{mmole})$ after that $(\mathrm{pH}$ was adjusted up to $\sim 7.5$ using $\mathrm{N}$-methyl morpholine). The reaction mixture was stirred for additional $3 \mathrm{hr}$ at the same temperature, for $12 \mathrm{hr}$ at room temperature, after which it was washed with water, $1 \mathrm{~N}$ sodium bicarbonate, $0.5 \mathrm{~N} \mathrm{HCl}$ and finally with water, then it was dried over anhydrous sodium sulphate. The solvent was evaporated to dryness and the obtained residue was solidified by trituration with diethyl ether. The obtained solid (1a or $1 \mathrm{~b}$ ) was then filtered off, washed with pet.ether.

\section{Mixed anhydride method}

Triethylamine $(0.13 \mathrm{ml}, 1 \mathrm{mmol})$ was added to a cold and stirred dichloromethane solution $\left(25 \mathrm{ml},-20^{\circ} \mathrm{C}\right)$ of valproic acid and ethyl chloroformate $(0.1 \mathrm{ml}, 1 \mathrm{mmole})$. Stirring was continued for $20 \mathrm{~min}$ after which the amino acid ester $\left(1\right.$ mmole) was added. The reaction mixture was stirred at $\sim-20^{\circ} \mathrm{C}, \mathrm{pH} \sim 7.5$ for $3 \mathrm{hr}$, then for $12 \mathrm{hr}$ at room temperature. The solution was then washed with water, $1 \mathrm{~N}$ hydrochloric acid, $1 \mathrm{~N}$ sodium bicarbonate and water followed by drying over anhydrous sodium sulphate. The solvent was evaporated under reduced pressure and the crude product was triturated with diethyl ether, filtered off, to afford the corresponding ester (1a or $1 \mathrm{~b}$ ).

1a: $\mathrm{C}_{12} \mathrm{H}_{23} \mathrm{NO}_{3}$ (229.32), m.p., 80-81 ${ }^{\circ} \mathrm{C}$ and 1b: $\mathrm{C}_{13} \mathrm{H}_{25} \mathrm{NO}_{3}$ (243.34), m.p., $71-$ $72{ }^{\circ} \mathrm{C}$.

TABLE 1. Spectral data for N-valproyl amino acid esters (1a, b).

\begin{tabular}{|l|l|}
\hline Spectral Data & Strcutural Formula \\
\hline IR $\left(\mathrm{KBr}, \mathrm{cm}^{-1}\right): 3297(\mathrm{NH}$ st.), $2956(\mathrm{CH}$ \\
aliphatic), $1731(\mathrm{C}=\mathrm{O}$ ester), 1640, 1550 \\
$(\mathrm{C}=\mathrm{O}$ stretching, amide $\mathrm{I}$ and $\mathrm{N}-\mathrm{H}$ \\
bending, amide II). \\
$M S(\mathrm{~m} / \mathrm{z} \%): 229\left(\mathrm{M}_{\mathbf{*}}^{+}, 1 \%\right), 187(55 \%)$, \\
$158(100 \%), 57(92 \%)$.
\end{tabular}

Synthesis of $N^{\alpha}$-valproyl glycyl hydrazones

Hydrazine hydrate $(98 \%, 0.35 \mathrm{ml}, \sim 10 \mathrm{mmol})$ was added to a methanolic solution $(20 \mathrm{ml})$ of compounds $1 \mathrm{a}(1 \mathrm{mmol})$. The reaction mixture was refluxed for $3 \mathrm{hr}$, after which the solvent was evaporated. The obtained residue was Egypt. J. Chem. 53, No. 2 (2010) 
triturated with ether, filtered off and crystallized from methanol/diethyl ether to give the corresponding hydrazide (2a).

A stirred solution of the hydrazide $2 \mathrm{a}(1 \mathrm{mmol})$, in ethanol $(20 \mathrm{ml})$ and vanillin or anisaldehyde $(1 \mathrm{mmol})$ was refluxed for $5 \mathrm{hr}$ with stirring. The reaction mixture was evaporated under reduced pressure, the obtained residue was triturated with ether. The separated solid was collected by filtration, dried and crystallized from ethanol/ether to give the corresponding hydrazones ( $3 \mathrm{a}, \mathrm{b})$.

2a: $\mathrm{C}_{10} \mathrm{H}_{21} \mathrm{~N}_{3} \mathrm{O}_{2}$ (215.29) m.p., 130-133 ${ }^{\circ} \mathrm{C} ; 3 \mathrm{a}: \mathrm{C}_{18} \mathrm{H}_{27} \mathrm{~N}_{3} \mathrm{O}_{4}$ (349.42) m.p., $187-$ $188^{\circ} \mathrm{C} 3$ b: $\mathrm{C}_{18} \mathrm{H}_{27} \mathrm{~N}_{3} \mathrm{O}_{3}$ (333.43), m.p., 204-206 ${ }^{\circ} \mathrm{C}$.

\section{TABLE 2. Spectral data.}

\begin{tabular}{|c|c|}
\hline Spectral Data & Strcutural Formula \\
\hline $\begin{array}{l}\text { IR }\left(\mathrm{KBr}, \mathrm{cm}^{-1}\right): 3292(\mathrm{NH} \mathrm{st}), 2941(\mathrm{CH} \text { aliphatic), } \\
1635,1560(\mathrm{C}=\mathrm{O} \text { stretching, amide I and } \mathrm{N}-\mathrm{H} \\
\text { bending, amide II). } \\
M S \quad(\mathrm{~m} / \mathrm{z} \quad \%): 173.11 \quad\left(\mathrm{M}_{*}^{+} \quad 42, \quad 12.7 \%\right), \\
149.11(56 \%), 83(51 \%), 57(100 \%) .\end{array}$ & \\
\hline 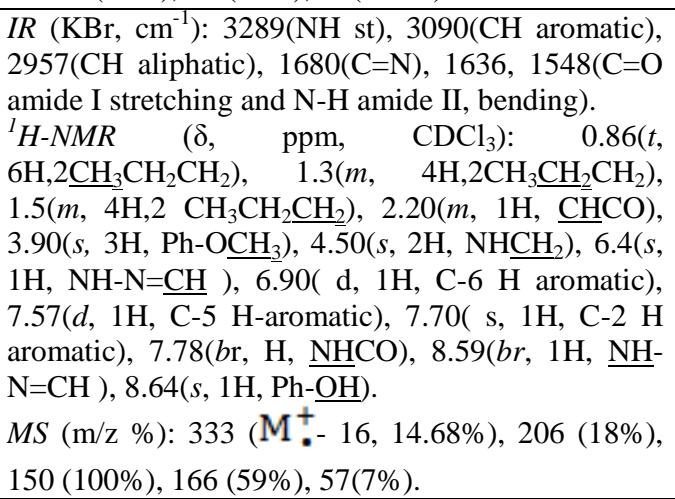 & $(3 a)$ \\
\hline 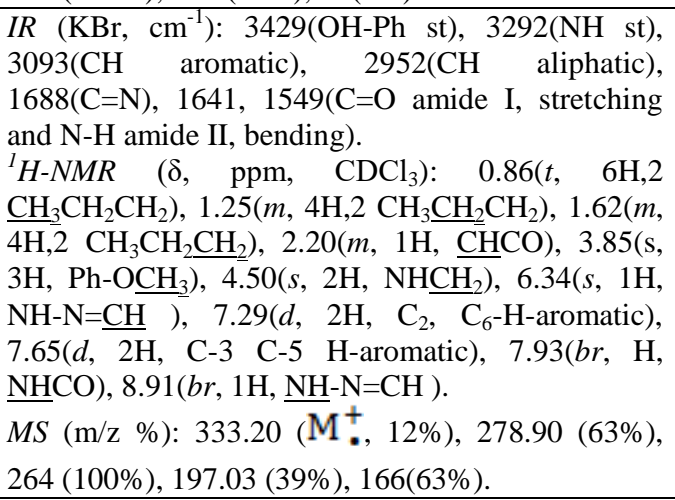 & \\
\hline
\end{tabular}


Synthesis of $N$-valproyl dipeptide esters and amides

Sodium hydroxide $(0.5 \mathrm{~N}, 20 \mathrm{ml})$ was dropwisely added to a cold and stirred methanolic solution $\left(1 \mathrm{mmol},-5{ }^{\circ} \mathrm{C}\right.$,) of the corresponding ester (1a or $\left.1 \mathrm{~b}\right)$. The cold reaction mixture $\left(4{ }^{\circ} \mathrm{C}\right)$ was acidified with $(1 \mathrm{~N})$ hydrochloric acid to $\mathrm{pH} \sim 3$. The obtained solid was filtered off, washed with water, dried and crystallized from ethanol/water to give the corresponding acids (4a, b).

The mixed anhydride method, was followed as previously described for (1a, b) to give the corresponding valproyl dipeptide esters $(5 \mathrm{a}, \mathrm{b})$.

Diisopropyl carbodiimide method: glycine ethyl ester, $1 \mathrm{mmol}$, was added to a solution $\mathrm{N}^{\gamma}$-valproyl GABA (4b) (1 mmol) in dichloromethane $\left(20 \mathrm{ml},-5^{\circ} \mathrm{C}\right)$. Diisopropylcarbodiimide $(0.26 \mathrm{ml}, 1 \mathrm{mmol})$ was added. The solution was then stirred for $20 \mathrm{hr}$ at room temperature, washed with $1 \mathrm{~N}$ sodium bicarbonate, $0.5 \mathrm{~N}$ $\mathrm{HCl}$ and water, dried $\left(\mathrm{Na}_{2} \mathrm{SO}_{4}\right)$ and evaporated under reduced pressure. The obtained oily residue was solidified by trituration with dry ether/n-hexane mixture, filtered off and crystallized from ethanol/diethyl ether to give the corresponding dipeptide ester (5b).

To a cold methanolic solution of $5 \mathrm{a}$ or $5 \mathrm{~b}\left(1 \mathrm{mmol}, 20 \mathrm{ml}\right.$, at $\left.-5{ }^{\circ} \mathrm{C}\right)$ a current stream of dry ammonia gas was passed till saturation. The reaction mixture was left over night at $\sim-4{ }^{\circ} \mathrm{C}$, evaporated under reduced pressure and the obtained residue was triturated with diethyl ether. The formed solid was filtered off, washed with ether, dried and crystallized from methanol/diethyl ether to give the corresponding amides $(6 \mathrm{a}, \mathrm{b})$ :

4a: $\mathrm{C}_{10} \mathrm{H}_{9} \mathrm{NO}_{3}$ (201.26), m.p., 122-123 ${ }^{\circ} \mathrm{C}$;

4b: $\mathrm{C}_{12} \mathrm{H}_{23} \mathrm{NO}_{3}$ (229.32) m.p., 68.5-69 ${ }^{\circ} \mathrm{C}$;

5a: $\mathrm{C}_{15} \mathrm{H}_{28} \mathrm{~N}_{2} \mathrm{O}_{4}$ (300.39) m.p., $120-121^{\circ} \mathrm{C}$;

5b: $\mathrm{C}_{16} \mathrm{H}_{30} \mathrm{~N}_{2} \mathrm{O}_{4}$ (314.42) m.p., $119-120^{\circ} \mathrm{C}$;

6a: $\mathrm{C}_{14} \mathrm{H}_{27} \mathrm{~N}_{3} \mathrm{O}_{3}$ (285.38), m.p., 126-127 ${ }^{\circ} \mathrm{C}$;

6b: $\mathrm{C}_{14} \mathrm{H}_{27} \mathrm{~N}_{3} \mathrm{O}_{3}(285.21)$, m.p., 103-105 ${ }^{\circ} \mathrm{C}$.

Egypt. J. Chem. 53, No. 2 (2010) 
TABLE 3. Spectral data.

\begin{tabular}{|c|c|}
\hline Spectral Data & Structural Formula \\
\hline $\begin{array}{l}I R\left(\mathrm{KBr}, \mathrm{cm}^{-1}\right): 3305-3110(\mathrm{OH} \text { and } \mathrm{NH} \text { st }), 2945(\mathrm{CH} \\
\text { aliphatic), } 1706(\mathrm{C}=\mathrm{O} \text { acid }), 1612,1493(\mathrm{C}=\mathrm{O} \text {, stretching, } \\
\text { amide I and } \mathrm{N}-\mathrm{H}, \text { bending, amide } \mathrm{II}) . \\
M S(\mathrm{~m} / \mathrm{z} \%): 201\left(\mathrm{M}_{*}^{+}, 19.1 \%\right), 184(10.6 \%), 131(38.3 \%), 99 \\
(29.8 \%), 84(23 \%), 57(100 \%) .\end{array}$ & \\
\hline $\begin{array}{l}I R\left(\mathrm{KBr}, \mathrm{cm}^{-1}\right): 3305-3199(\mathrm{OH} \text { and } \mathrm{NH} \text { st }), 2960(\mathrm{CH} \\
\text { aliphatic }), 1704(\mathrm{C}=\mathrm{O} \text { acid }), 1635,1550(\mathrm{C}=\mathrm{O} \text { stretching, } \\
\text { amide I and } \mathrm{N}-\mathrm{H} \text { bending, amide II }) . \\
M S(\mathrm{~m} / \mathrm{z} \%): 230.14\left(\mathrm{M}_{-}^{+}+1,100 \%\right), 187(27 \%), 158(17 \%), \\
140(10 \%), 57(19 \%) .\end{array}$ & \\
\hline $\begin{array}{l}I R\left(\mathrm{KBr}, \mathrm{cm}^{-1}\right): 3303(\mathrm{NH} \text { st }), 2956(\mathrm{CH} \text { aliphatic }), 1730(\mathrm{C}=\mathrm{O} \\
\text { Ester }), 1639,1550(\mathrm{C}=\mathrm{O} \text { stretching amide I and } \mathrm{N}-\mathrm{H} \text { bending, } \\
\text { amide II). } \\
M S(\mathrm{~m} / \mathrm{z} \%): 301\left(\mathrm{M}_{-}^{+}+1.100 \%\right), 283(6 \%), 258(23 \%), 229.2 \\
(18 \%), 184(16 \%), 157.2(18 \%), 57(37 \%) .\end{array}$ & \\
\hline $\begin{array}{l}I R\left(\mathrm{KBr}, \mathrm{cm}^{-1}\right): 3289(\mathrm{NH} \text { st }), 2958(\mathrm{CH} \text { aliphatic }), 1748(\mathrm{C}=\mathrm{O} \\
\text { ester), } 1642,1553(\mathrm{C}=\mathrm{O} \text { stretching amide I and } \mathrm{N}-\mathrm{H} \text { bending, } \\
\text { amide II). } \\
M S(\mathrm{~m} / \mathrm{z} \%): 314\left(\mathrm{M}_{*}^{+}, 2.8 \%\right), 272(9.1 \%), 243(13.6 \%), 170 \\
(19 \%), 158(31 \%), 127(11.8 \%), 86(46 \%), 57(100 \%) .\end{array}$ & \\
\hline 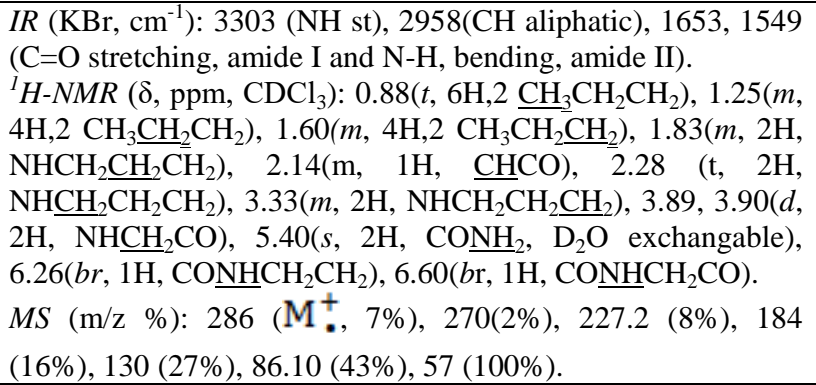 & (6a) \\
\hline 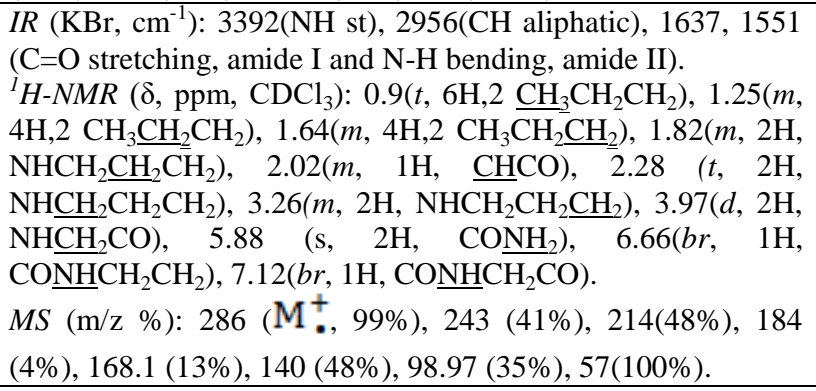 & \\
\hline
\end{tabular}




\section{Anticonvulsant Screening}

The assays were realized in the Pharmacology Unit, NRC, Cairo, Egypt.

\section{Animals}

The experimental work was based on male albino mice. Animals, weighing 20gm. each, were obtained from the "Animal House" (National Research Centre Cairo, Egypt) and were kept under hygienic conditions, during which they were fed on standard pellet chow and water was provided $a d-l i b$.

\section{Statistical analysis of results}

Valproic acid and dimethylsulfoxide (DMSO) were considered as the reference drug and negative control, respectively.

The obtained data were statistically analyzed vis-à-vis the control then valproic acid, as therein indicated. The "Least Significant Difference Test (LSD, SPSS statistics, 17.0" software, IBM $^{\circledR}$ ) was statistically manipulated.

Maximal electroshock seizure test (MES).

\section{Material and Methods}

The test was, principally, realized according to krall, et al. ${ }^{(17)}$ and Kitona et al. ${ }^{(18)}$. A candidate under investigation was p.o. given to a group of six mice $(10 \mathrm{mg} / \mathrm{kg})$. One hour later, an increased electric current (starting from $1 \mathrm{~mA}$ ) was applied via an ear electrode, for 0.2 seconds and at $50 \mathrm{~Hz}$ (Ugo Basil, ECT Unit, 57800).

Tonic extension of the hind limbs is taken as the end point ${ }^{(19)}$. The mean convulsion threshold was considered as the mean of the maximal electric current which could be tolerated by the animal at the end point.

Results

Results of the MES test were expressed in mili-Ampere of the mean convulsion threshold for each candidate. The obtained values represent a mean of that of six mice ( \pm standard error).

Statistical analysis of the results

1- LSD test (vis-à-vis control)

$L S D$ test was applied to determine the significant activity, considering $\mathrm{P}<0.05$, while compared to the control. All tested compounds were found statistically significant at $(10 \mathrm{mg} / \mathrm{kg})$, except $N^{\prime \prime}$-valproyl-aminobutryl-glycine amide $(6 \mathrm{~b})$.

2- LSD test (vis-à-vis valproic acid)

Compound (6a) was found statistically significant, compared to valproic acid $(\mathrm{P} \leq 0.05)$. 
TABLE 4. Anticonvulsant potency of the tested candidates, (MES test).

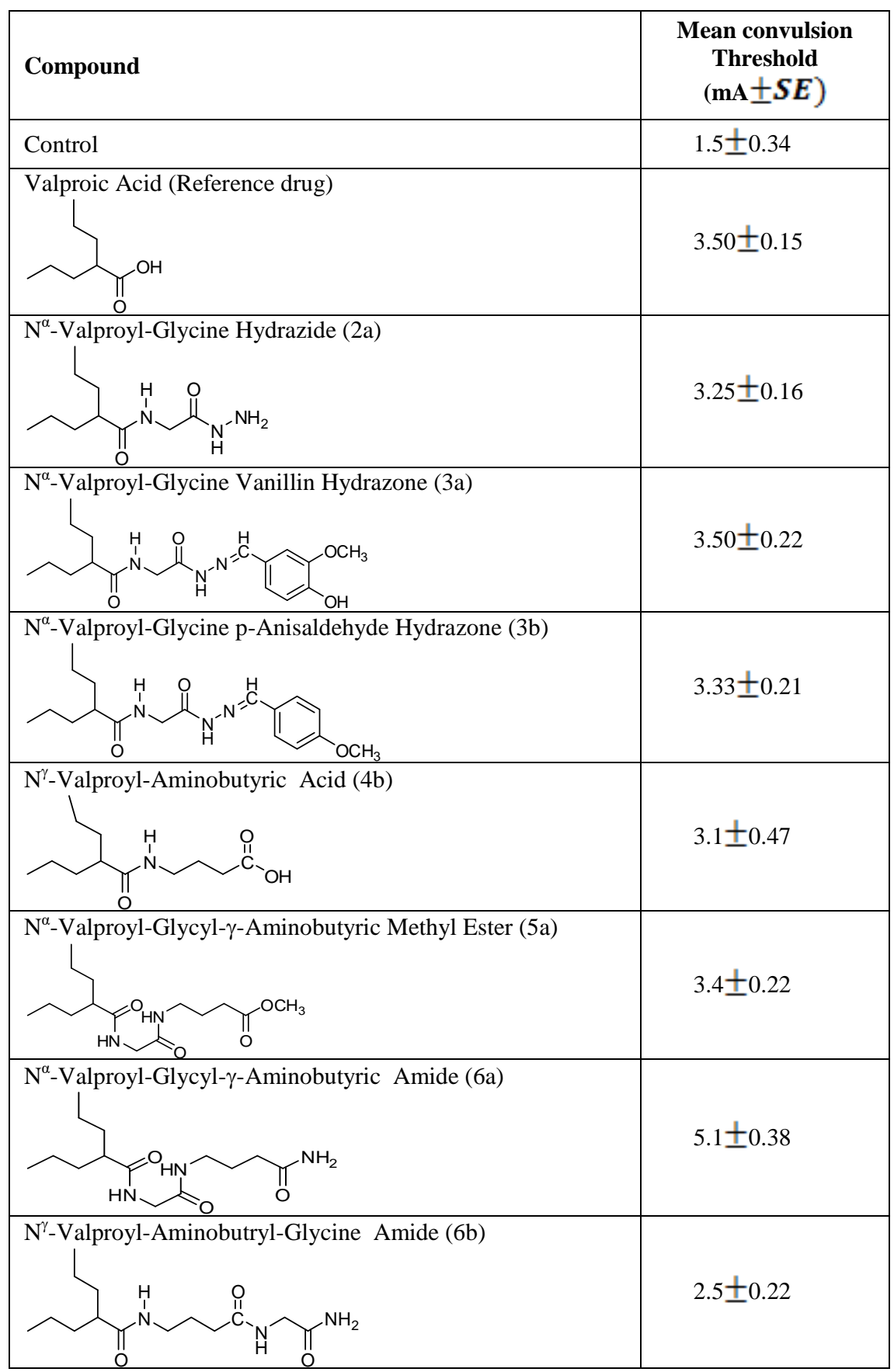


Principally, the maximal electroshock seizure test (MES), as a mean of electro-shock inducing convulsions, reflecting the generalized tonic-clonic (grand mal) type of epileptic seizures, was adopted ${ }^{(20)}$. The method was reported as, probably, the best validated for evaluating of antiepileptic drugs ${ }^{(18,19)}$.

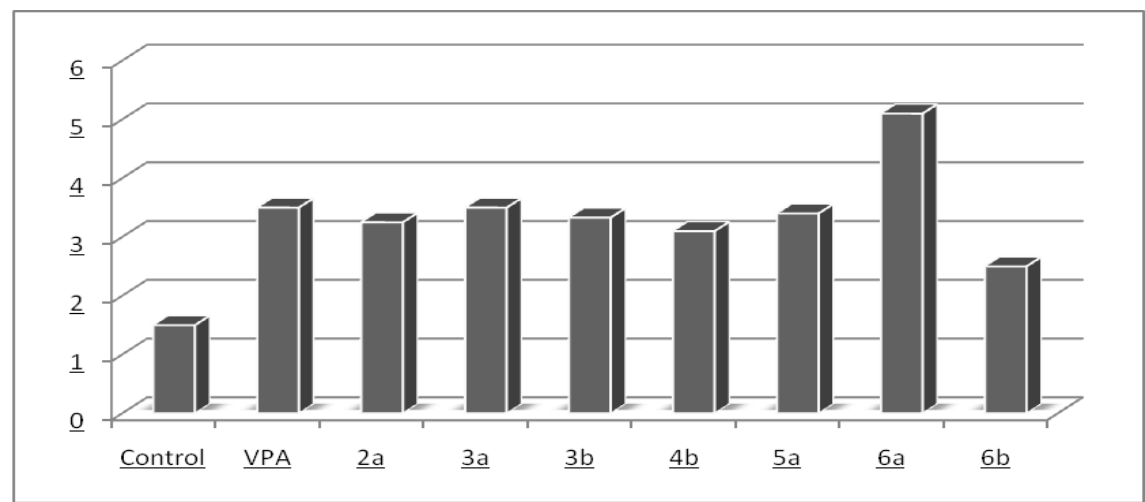

Fig. 1. Anticonvulsant potency of the synthesized compounds, valproic acid and control.

From the molecular structural point of view, the least active dipeptide candidate $\mathrm{N}^{\alpha}$-valproyl-aminobutryl-glycine amide (6b), however, the alteration of the amino acid positions in its peptide sequence, to be $\mathrm{N}^{\alpha}$-valproyl-glycyl- $\gamma$ aminobutyric amide (6a), was associated with an enhanced activity.

\section{Conclusions and Perspectives}

The starting conceptual hypothesis of the probable amelioration of the biological activity, namely, anticonvulsant potency upon conjugation with rationalized amino acids or peptides derivatives, seemed herein, explicitly validated.

The novel amino acid dipeptide conjugate of the neuroinhibitor amino acids glycine and $\gamma$-aminobutric acid (6a) proved as statistically significant anticonvulsants and more potent than the parent drug valproic acid, in the protection of the generalized tonic-clonic seizurs (grand mal) animal model (MES), of epileptic convulsions.

The realized results could be, promisingly, extrapolated to encounter additional rationalized amino acid and peptide structural variations, as well as more profound pharmacological, namely, toxicological and pharmacokinetic investigations. 


\section{References}

1. Workman, E.A., "Neuropharmacology"; Encyclopedia of the Human Brain". Elsevier Science, 3, 546-560 (2002).

2. Watanabe, M., Maemura, K., Kanbara, K., Tamayama, T. and Hayasaki, H., Int. Rev. Cytol. 213, 1-47 (2002).

3. Elger, C.E. and Schmidt, D., Modern management of epilepsy: A practical approach, Epilepsy \& Behavior, 12, 501-539 (2008).

4. Aires, C.C.P., Jlst, L.I., Stet, F., Prip-Buus, C., Tavares de Almeida, I., Duran, M., Wanders, R.J.A. and Silva M. F.B., Inhibition of hepatic carnitine palmitoyltransferase I (CPT IA) by valproyl-CoA as a possible mechanism of valproate-induced steatosis. Biochem.Pharm. 79, $792-799$ (2010).

5. Koren, G., Nava-Ocampo, A.A., Moretti, M.E., Sussman, R. and Nulman, I., Major malformations with valproic acid. Can. Fam. Physician, 52, 441-444 (2006).

6. Hadad, S. and Bialer, M., Pharmacokinetic analysis and antiepileptic activity of Nvalproyl derivatives of GABA and glycine. Pharmaceutical Res. 12, 905-910 (1995)

7. Rekatas, G.V., Tani, E., Demopoulos, V.J. and Kourounakis, P.N., Synthesis of GABA Valproic acid derivatives and evaluation of their anticonvulsant and antioxidant activity. Archiv. der Pharmazie, 329, 393-398 (1996).

8. Bialer, M., Johannessen, S.I., Kupferberg, H.J., Levy, R.H., Perucca, E. and Tomson, T., Progress report on new antiepileptic drugs: A summary of the seventh Eilat conference on new antiepileptic drugs (EILAT VII). Epilepsy Res. 61, 1-48 (2004).

9. Sussan, S., Dagan, A. and Bialer, M., Pharmacokinetic analysis and anticonvulsant activity of glycine and glycinamide derivatives. Epilepsy Res. 33, 11-21(1999).

10. Isoherranen, N., Woodhead, J., White, H. and Bialer, M., Anticonvulsant profile of valrocemide (TV1901): a new antiepileptic drug. Epilepsi, 42, 831-836 (2001).

11. Bialer, M., Johannessen, S.I., Levy, R.H., Perucca, E., Tomson, T. and Steve White, H., Progress report on new antiepileptic drugs: A summary of the ninth Eilat conference (EILAT IX)., Epilepsy Res. 83, 1-43 (2009).

12. Goodman, M., Felix, A., Moroder, L. and Toniolo, C. (Ed.), "Synthesis of Peptides and Peptidomimetics, Houben-Weyl, Methods of Organic Chemistry", $4^{\text {th }}$ ed., Vol. E22, Thieme (2000).

13. Bodanszky, M. and Bodanszky, A., "The Practice of Peptide Synthesis", SpringerVerlag (Ed.) (1984).

14. Erdélyi L., Vanillin modulates the fast outward and calcium currents in Helix neurons. Acta. Biol. Hung. 43, 15-24 (1992).

15. Janahmadi, M., Farajnia, S., Vatanparast, J., Abbasipour, H. and Kamalinejad, M., The fruit essential oil of Pimpinella anisum L.(Umblliferae) induces neuronal hyperexcitability in snail partly through attenuation of after-hyperpolarization. $J$. Ethnopharmacol. 120, 360-365 (2008).

16. Pourgholami, M.H., Majzoob, S., Javadi, M., Kamalinejad, M., Fanaee, G.H.R. and Sayyah, M., The fruit essential oil of Pimpinella anisum exerts anticonvulsant effects in mice. J. Ethnopharmacol. 66, 211-215 (1999).

Egypt. J. Chem. 53, No. 2 (2010) 
17. Krall, R.L., Penry, J.K., White, B.G., Kupferberg, H.J. and Swinyard, E.A. Antiepileptic drug Development: II. Anticonvulsant drug screening. Epilepsia, 19, 409-428 (1978).

18. Kitano, Y., Usui, C., Takasuna, K., Hirohashi, M. and Nomura, M., Increasingcurrent electroshock seizure test: A new method for assessment of anti- and proconvulsant activities of drugs in mice. J. Pharmacol. Toxicol. Meth. 35, 25-29 (1996).

19. Löscher, W., Nau, H., Marescaux, C. and Vergnes, M., Comparative evaluation of anticonvulsant and toxic potencies of valproic acid and 2-ene-valproic acid in different models of epilepsy. Euro. J. Pharmacol. 99, 211-218 (1984).

20. Luszczki, J.J., Sawicka, K.M., Kozinska, J., Borowicz, K.K. and Czuczwar, S.J., Furosemide potentiates the anticonvulsant action of valproate in the mouse maximal electroshock seizure model, Epilepsy Res. 76, 66-72 (2007).

(Received 12/4/2010; accepted 21/4/2010)

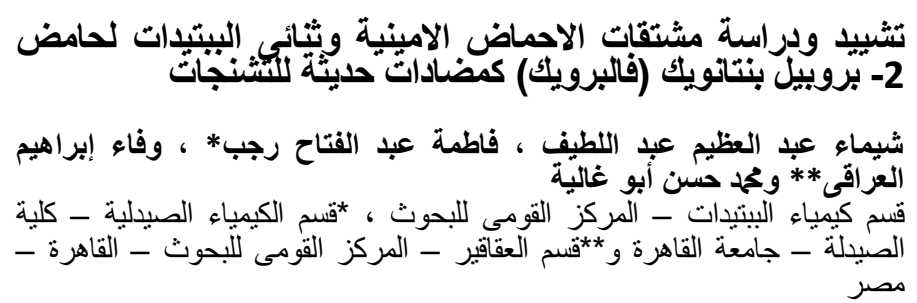

يهدف البحث إلى دراسة فرض إمكانية تحسين فاعلية المواد النشطة بيولوجيا بصفة

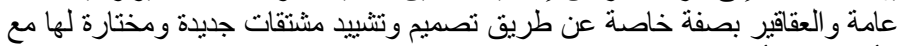

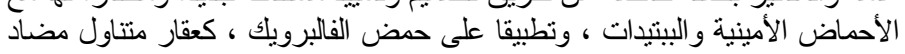

للتشنجات الصر عية الامينة

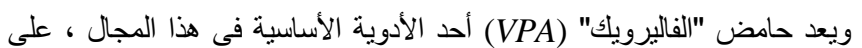

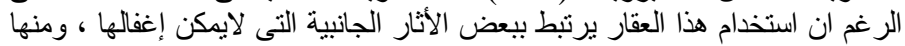

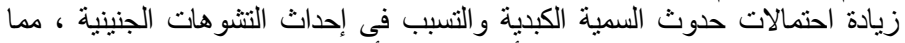

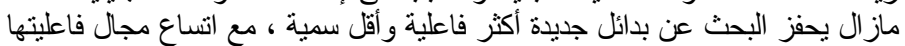

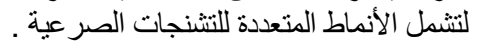

و انطلاقا من ذلك فقد بدا مجديا، وكهدف لذلك البحث اقتر اح التصميم البنائى ثم التمبن

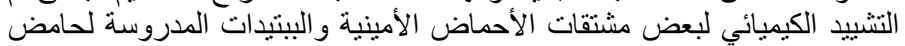

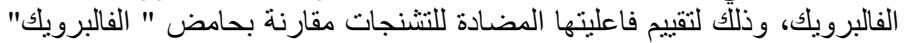

وتحديدا لما أجمل فيما سلف ، فقد نم التشبيد الكيميائى لمركبات جديدة وهى :

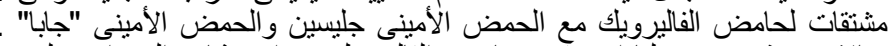

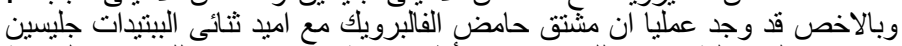

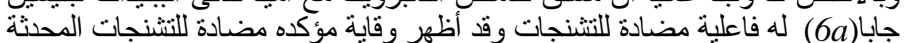
كهربائيا مع الجرعة المستخدة

وأخير يتضح أن الافتراض المبلئى بإمكان تحسين الفاعلية البيولوجية المضادة البادية

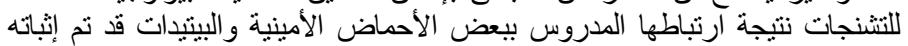

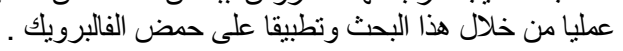

Egypt. J. Chem. 53, No. 2 (2010) 